\title{
Production and calving traits of Montbéliarde $\times$ Holstein and Viking Red $\times$ Holstein cows compared with pure Holstein cows during first lactation in $\mathbf{8}$ commercial dairy herds
}

A. R. Hazel, ${ }^{1}$ B. J. Heins, and L. B. Hansen

Department of Animal Science, University of Minnesota, St. Paul 55108

\begin{abstract}
Montbéliarde $(\mathrm{MO}) \times$ Holstein $(\mathrm{HO})$ and Viking Red $(\mathrm{VR}) \times \mathrm{HO}$ crossbred cows were compared with pure HO cows in 8 large, high-performance dairy herds. All cows were either 2-breed crossbred or pure HO cows that calved for the first time from December 2010 to April 2014. Best Prediction was used to calculate 305-d milk, fat, and protein production, as well as somatic cell score, and $513 \mathrm{MO} \times \mathrm{HO}, 540 \mathrm{VR} \times \mathrm{HO}$, and $978 \mathrm{HO}$ cows were analyzed for production in first lactation. Calving difficulty was scored from 1 (no assistance) to 5 (extreme difficulty). The analysis of calving traits included $493 \mathrm{MO} \times \mathrm{HO}, 504 \mathrm{VR} \times \mathrm{HO}$, and $971 \mathrm{HO}$ cows at first calving. Age at first calving was similar for breed groups, and the herds calved both crossbred (23.8 mo) and HO (23.9 mo) cows at young ages. The $\mathrm{MO} \times \mathrm{HO}$ crossbred cows had $+3 \%$ higher production of 305-d fat plus protein production (actual basis, not mature equivalent) than the $\mathrm{HO}$ cows, and the $\mathrm{VR} \times$ $\mathrm{HO}$ were similar to the $\mathrm{HO}$ cows for fat plus protein production. Breed groups did not differ for SCS during first lactation. The VR-sired 3-breed crossbred calves (from $\mathrm{MO} \times \mathrm{HO}$ dams) were similar to pure $\mathrm{HO}$ calves for calving difficulty; however, MO-sired male calves born to VR $\times$ HO dams had a mean score that was +0.5 points higher for calving difficulty than pure $\mathrm{HO}$ male calves. The 3-breed crossbred calves from both $\mathrm{MO} \times \mathrm{HO}(4 \%)$ and $\mathrm{VR} \times \mathrm{HO}(5 \%)$ first-lactation dams had a much lower stillbirth rate compared with pure HO calves $(9 \%)$ from first-lactation dams.
\end{abstract}

Key words: crossbreeding, Montbéliarde, Viking Red

\section{INTRODUCTION}

Crossbreeding of dairy cattle has not been the predominant breeding strategy for commercial milk production during the late 20th century, which is con-

Received August 11, 2016.

Accepted January 3, 2017.

${ }^{1}$ Corresponding author: haze0025@umn.edu trary to the routine breeding strategies for commercial production of the beef, swine, and poultry industries. However, the use of crossbreeding in dairy cattle is on the rise globally. Among cows enrolled in milk recording in the United States, crossbreds have had a 9-fold increase from $0.5 \%$ in 2003 to $4.5 \%$ in 2014 (VanRaden and Sanders, 2003; Norman et al., 2015). Crossbreeding of Holstein-Friesian and Jersey has become the prevailing breeding strategy in New Zealand, where crossbreds were $46 \%$ of cows in 2014 (LIC and DairyNZ, 2015). In Ireland, crossbreds were $10.6 \%$ of dairy cattle births in 2015 (Department of Agriculture, Food and the Marine, 2015).

Interest in crossbreeding for commercial milk production has grown over the past $20 \mathrm{yr}$ because dairy herd owners desire robust dairy cows that have enhanced health, fertility, and longevity than provided by purebreds (Weigel and Barlass, 2003). Another reason for heightened interest in crossbreeding is growing concern about the accelerated increase in inbreeding of Holstein (HO) cows, because inbreeding has incrementally negative effects on performance and profitability of cows (Dezetter et al., 2015). During the past 5 yr, the annual increase of mean inbreeding coefficient doubled from +0.1 to $+0.2 \%$ in the United States and is the consequence of the shortened generation interval that has accompanied genomic selection (Dechow, 2014). Dezetter et al. (2015) recently studied inbreeding depression in $\mathrm{HO}$ cows, and the $6.8 \%$ average inbreeding of US pure HO females born in 2016 (Council on Dairy Cattle Breeding, 2016) converts to an estimated loss of $-279 \mathrm{~kg}$ of milk, $-12 \mathrm{~kg}$ of fat, and $-9 \mathrm{~kg}$ of protein production per 305-d lactation.

Previous comparisons of crossbreds with HO cows in exclusively high-input environments (Blöttner et al., 2011; Heins et al., 2012; Heins and Hansen, 2012) and in national data with various levels of inputs (VanRaden and Sanders, 2003; Dechow et al., 2007; Dezetter et al., 2015) have documented the need for further evaluation of crossbreds as replacements for $\mathrm{HO}$ cows in high-performance confinement herds. In particular, a 3-breed rotation including Montbéliarde (MO) from 
France, Viking Red (VR) from Scandinavia, and HO may be well suited to those environments. The VR breed was recently formed as a result of combining the genetic improvement programs for the Swedish Red, Finnish Ayrshire, and Danish Red breeds, which have historically shared genetic material and applied similar selection criteria with emphasis on the fertility and health of cows. Several studies have reported results of Montbéliarde $\times$ Holstein crossbred $(\mathbf{M O} \times \mathbf{H O})$ compared with HO cows (Walsh et al., 2008; Malchiodi et al., 2014; Dezetter et al., 2015) as well as Viking Red $\times$ Holstein crossbred $(\mathbf{V R} \times \mathbf{H O})$ compared with $\mathrm{HO}$ cows (Ericson et al., 1988; Swalve, 2007; Sørensen et al., 2008) in various environmental settings.

Most research on crossbreeding of dairy cattle has reported results from analysis of field data, which has often had very unbalanced numbers of cows per breed group, little regard for genetic merit of cows within breed, breed groups of cows not reared in the same environment, or only a single-herd comparison. The present long-term study overcomes these challenges by the careful assignment of the "foundation" pure HO cows to the base generation for each breed group and by maintaining control over the successive generations of matings. Eventually, this research project will study data over lifetimes of cows from multiple generations of a 3-breed rotation of MO, VR, and $\mathrm{HO}$.

The objective of this research was to analyze phenotypes for 305-d production, SCS, and calving traits from the first lactations of $\mathrm{MO} \times \mathrm{HO}$ and $\mathrm{VR} \times \mathrm{HO}$ crossbred cows compared with pure $\mathrm{HO}$ cows in a 10-yr designed study.

\section{MATERIALS AND METHODS}

\section{Experimental Design}

Description of Herds and Cows Enrolled. Pure HO females in 8 dairy herds were offered by herd owners as "foundation" females for a 10-yr genetic study from March to September of 2008. Across the 8 herds, 3,550 nulliparous heifers as well as cows (primarily first or second lactation) were committed. The 8 herds are located in southeastern, southwestern, and central Minnesota and are elite herds for production. Cows in all herds were housed in a 4- or 6-row freestall confinement facility and fed a TMR during lactation. In May 2016, the herds ranged in size from 295 to 1,932 cows with a mean herd size of 791 cows and weighted mean production across the 8 herds of 13,918 kg of milk, 510 $\mathrm{kg}$ of fat, and $430 \mathrm{~kg}$ of protein with 3 times daily milking. The collective mean production levels of these 8 herds placed them among the 94th percentile for mean milk, fat, and protein production for Minnesota herds enrolled in milk recording in June of 2016 (Dairy Records Management System, Raleigh, NC, personal communication).

The herds exceeded many benchmarks for wellmanaged dairy herds when the study was initiated; however, interest of the herd owners in the study was driven by a desire to reduce labor costs, to lessen the need for health treatment, and to minimize hormonal synchronization for fertility. The herds co-mingled the crossbred and HO cows at all times, and they grouped cows only by age, stage of lactation, and fertility status. Also, the herds applied the same management criteria across all breed groups, including criteria for health treatment and culling.

Mating Design. The authors assigned the foundation females offered by the herd owners to either the crossbred or the HO breed groups. The foundation heifers and cows were grouped for assignment to breed groups based on age and sire for heifers, and on lactation number, sire, and projected mature equivalent milk production for cows.

All herds offered a minimum of 250 foundation pure HO females, of which 150 were mated to HO bulls through successive generations and 100 were mated to either MO or VR bulls to initiate the 3-breed rotation. Within the 2 crossbred groups, the resulting $F_{1}$ crossbred progeny were mated via AI to the third breed (i.e., $\mathrm{MO} \times \mathrm{HO}$ cows were mated to VR bulls and the VR $\times \mathrm{HO}$ cows were mated to MO bulls) to create 3 -breed crossbred cattle.

In many cases, herd owners chose to enroll more than 250 foundation pure $\mathrm{HO}$ heifers and cows, and they designated to which breed group (crossbred or HO) the additional animals were enrolled. Across the herds, approximately $56 \%$ of the foundation $\mathrm{HO}$ females were mated to either MO or VR bulls with exactly half mated to bulls from each of the 2 breeds. The other approximately $44 \%$ of the foundation $\mathrm{HO}$ cattle were bred to HO bulls.

Heifers and cows were assigned individually to AI bulls for mating by 2 genetic advisors employed by Minnesota Select Sires Co-op Inc. (St. Cloud, MN). Both crossbred and HO cows were correctively mated for conformation, and heifers were correctively mated based on the conformation scores of their dam when possible. Additionally, inbreeding protection was provided for matings of $\mathrm{HO}$ bulls to $\mathrm{HO}$ cows and heifers. Some of the herds mated cows on fifth and later services to unproven AI bulls or natural service bulls, but the resulting progeny were excluded from the study.

Only proven AI bulls with very high rank for genetic merit from each of the 3 breeds were selected to breed the heifers and cows in the study. Herd owners chose the AI bulls for each breed in consultation with the 2 
Table 1. Most frequent sires of cows that composed $75 \%$ of the cows in each breed group of first lactation cows

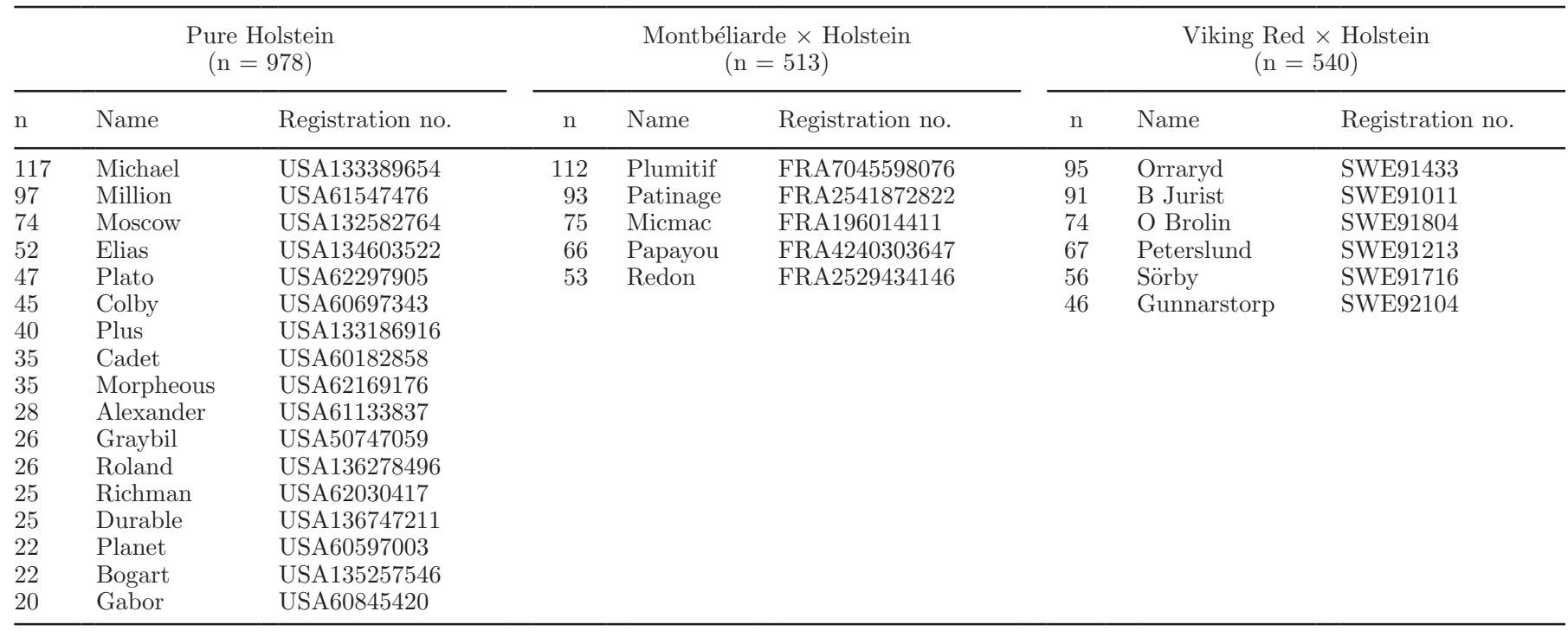

genetic advisors. For MO and VR bulls, all semen was imported to the United States by Creative Genetics of California (Oakdale, CA). The bulls ranked highly among those available in the United States based on the French ISU index (O. S. Montbéliarde, 2016) and the Nordic Total Merit index (Nordic Cattle Genetic Evaluation, 2016), which are the national selection indices for the MO and VR breeds, respectively. All HO bulls were proven AI bulls marketed by Select Sires Inc. (Plain City, OH), and herd owners were asked to select bulls that ranked among the top $10 \%$ of available bulls for the Net Merit index (VanRaden and Cole, 2014). The MO, VR, and HO breeds apply selection indices with, respectively, 45,36 , and $43 \%$ emphasis on production, $42.5,49$, and $41 \%$ emphasis on functional traits, and $12.5,15$, and $16 \%$ emphasis on conformation traits. However, the MO and VR breeds have a much longer history of selection for fertility and health traits compared with the HO breed, and this could improve their complementarity with HO for crossbreeding.

Sires of cows in this study were selected from 2008 to 2011 , which was 5 to 8 yr before the analysis of data from this study. The most frequent sires of cows in this study are reviewed in Table 1, which reports the sires of $75 \%$ of cows for each breed and reflects the bulls used most heavily during the first 4 yr of the study. The remaining $25 \%$ of cows were sired by 9 MO bulls, 10 VR bulls, and $45 \mathrm{HO}$ bulls. The weighted mean birth year for sires of cows was 1999 for both the $\mathrm{MO} \times \mathrm{HO}$ and VR $\times$ HO cows, but it was 4 yr younger (2003) for the HO cows. Therefore, the sires of the pure HO cows in this study likely had an advantage for genetic level respective to breed.

\section{Initial Data Editing}

Table 2 summarizes the initial editing of cows within each breed group. Calvings of cows that had gestation length (GL) less than $260 \mathrm{~d}$ were considered an abortion and were removed from the analysis. After initial editing, 1,105 crossbred and 1,101 HO cows with normal first calvings remained for analysis. Table 3 provides a summary of the number of cows by year of calving, herd, and breed group.

Table 2. Editing of cows by breed group

\begin{tabular}{lccc}
\hline Edit (no.) & $\begin{array}{c}\text { Pure } \\
\text { Holstein }\end{array}$ & $\begin{array}{c}\text { Montbéliarde } \\
\times \text { Holstein }\end{array}$ & $\begin{array}{c}\text { Viking Red } \\
\times \text { Holstein }\end{array}$ \\
\hline Viable females born & 1 & 633 & 642 \\
Left before first calving & 1,351 & 81 & 58 \\
Calved after April 2014 & 194 & 4 & 1 \\
Initiated first lactation with abortion & 23 & 9 & 17 \\
Remained for analysis & 33 & 539 & 566 \\
\hline
\end{tabular}

${ }^{1}$ Females with opportunity to calve for a first time from December 2010 to April 2014 and to milk 305 d into their first lactation. 
Table 3. Distribution of cows calving for the first time from December 2010 to April 2014 by year and breed group and by herd and breed group

\begin{tabular}{|c|c|c|c|c|}
\hline \multirow[b]{2}{*}{ Item } & \multicolumn{4}{|c|}{ Breed group } \\
\hline & $\begin{array}{c}\text { Pure } \\
\text { Holstein }\end{array}$ & $\begin{array}{c}\text { Both crossbred } \\
\text { groups }\end{array}$ & $\begin{array}{l}\text { Montbéliarde } \\
\times \text { Holstein }\end{array}$ & $\begin{array}{l}\text { Viking Red } \\
\times \text { Holstein }\end{array}$ \\
\hline \multicolumn{5}{|l|}{ Year } \\
\hline $2011^{1}$ & 362 & 461 & 215 & 246 \\
\hline 2012 & 321 & 399 & 198 & 201 \\
\hline 2013 & 326 & 214 & 111 & 103 \\
\hline 2014 & 92 & 31 & 15 & 16 \\
\hline \multicolumn{5}{|l|}{ Herd } \\
\hline $\mathrm{A}$ & 157 & 87 & 41 & 46 \\
\hline B & 126 & 57 & 30 & 27 \\
\hline $\mathrm{C}$ & 85 & 96 & 52 & 44 \\
\hline $\mathrm{D}$ & 213 & 183 & 91 & 92 \\
\hline $\mathrm{E}$ & 163 & 298 & 148 & 150 \\
\hline $\mathrm{F}$ & 132 & 202 & 100 & 102 \\
\hline G & 110 & 71 & 30 & 41 \\
\hline $\mathrm{H}$ & 115 & 111 & 47 & 64 \\
\hline Total & 1,101 & 1,105 & 539 & 566 \\
\hline
\end{tabular}

The design of the study ensured breed groups would have sufficient size for comparison within each year and within each herd. However, 2013 and 2014 were transition years of first calving between generations because the last of the $\mathrm{F}_{1}$ crossbreds $(\mathrm{MO} \times \mathrm{HO}$ and $\mathrm{VR} \times \mathrm{HO})$ calved for the first time and the majority of crossbreds that calved for the first time had shifted to the 3-breed crossbreds. Similarly, few of the first-generation HO cows calved during 2013 and 2014, and instead, most the HO cows used for comparison shifted to the second generation of HO cows. Therefore, the number of crossbreds calving in 2014 was smaller than the number of $\mathrm{HO}$ cows, and this difference for generation of the breed groups likely gave the $\mathrm{HO}$ cows an advantage for genetic level within breed.

\section{Trait Descriptions}

Production and SCS. Analysis of 305-d production of first-lactation milk, fat, and protein as well as SCS used test-day records from milk recording (DHI). Test days occurred monthly for 5 herds and at least 8 times per year for the other 3 herds. Individual test days of cows with fewer than 4 DIM were excluded, and each test day was required to have an observation for milk, fat, and protein production. Test-day milk weight was required to be at least $4.54 \mathrm{~kg}$, fat percentage was required to be at least $1.0 \%$ but no greater than $9.0 \%$, and protein percentage was required to be at least $1.0 \%$ but no greater than $6.0 \%$. Lactations were required to have at least 2 test days to project $305-\mathrm{d}$ production and SCS for cows that left herds before 305 DIM.
Daily milk, fat, and protein production and SCS were calculated with Best Prediction (BP; Cole and VanRaden, 2009), which is routinely used for genetic evaluation in the United States. The BP adjusted lactational records for age at first calving and projected daily production records to $305 \mathrm{~d}$ for records less than 305 d. The 305-d SCS for each cow was the mean of predicted daily SCS. The BP was applied separately to each of the 8 herds in this study, and herd-specific lactation curves were used to calculate 305 -d production (actual basis, not mature equivalent). Fat and protein percentages for each cow were calculated by dividing the 305-d fat and protein production $(\mathrm{kg})$, respectively, by $305-\mathrm{d}$ milk production $(\mathrm{kg})$. All 8 herds routinely milk most of their cows 3 times daily; however, $4 \%$ of test-day observations were for cows milked 2 times per day on specific test days. A chi-squared test indicated the crossbreds did not differ from HO cows for percentage of observations that were from 2-times-daily versus 3 -times-daily milking.

Calving Traits. The incidence of twinning (TW), GL, calving difficulty (CD), and stillbirth (SB) were recorded for calving events from December 2010 to April 2014. Owners or employees of herds recorded all of the calving traits except GL. Neither calf weight nor BW of dams were available.

The TW was recorded by herds in a binary manner as either a single birth or twins, and no cows gave birth to more than 2 calves. The GL was calculated by subtracting the date of conception from the calving date. A 5-point scale was used uniformly across herds to score CD, with $1=$ no assistance and less than 2 
$\mathrm{h}$ in labor, or calving was unobserved; $2=$ slight difficulty and more than $2 \mathrm{~h}$ in labor but no assistance was provided; $3=$ needed assistance, such as a hand pull; $4=$ difficult pull, such as obstetrical chains were used with significant force; $5=$ extreme difficulty, such as a mechanical puller was used or cesarean section was performed. The SB was recorded in a binary manner as either living or dead within $24 \mathrm{~h}$ of birth.

\section{Final Editing and Analysis}

Production and SCS. Lactations of cows without 2 test days (46 crossbred and $64 \mathrm{HO}$ cows) were removed from the analysis for production and SCS. Cows were assigned to a herd-year-season (HYS) of first calving, and HYS was defined as 4-mo periods (January to April, May to August, and September to December) within each herd; therefore, each herd had up to 11 HYS of first calving across the years of the study. The HYS were further edited to permit valid comparison of crossbreds to HO cows within each HYS. First, HYS were required to contain at least 3 crossbred $(\mathrm{MO} \times$ $\mathrm{HO}$ and $\mathrm{VR} \times \mathrm{HO}$ breed groups combined) and $3 \mathrm{HO}$ cows, and this requirement resulted in the removal of 6 crossbred and 59 HO cows across all HYS. Subsequently, the HYS that contained fewer than 3 of either $\mathrm{MO} \times \mathrm{HO}$ or $\mathrm{VR} \times \mathrm{HO}$ were combined with the adjacent HYS within herd that had the fewest cows in a breed group. This criteria was satisfied by combining 2 HYS in all cases, except 1 instance where 3 HYS were combined. After edits, the number of cows analyzed for production and SCS included 1,053 crossbred (513 MO $\times \mathrm{HO}$ and $540 \mathrm{VR} \times \mathrm{HO}$ ) and $978 \mathrm{HO}$ cows.

Independent variables for the statistical analysis of age at first calving, 305-d milk, fat, and protein production $(\mathrm{kg}), 305-\mathrm{d}$ fat plus protein production $(\mathrm{kg})$, and SCS included the fixed effects of HYS, breed of cow (crossbred or $\mathrm{HO}$ ), and breed group $(\mathrm{MO} \times \mathrm{HO}$ nested within crossbred or $\mathrm{VR} \times \mathrm{HO}$ nested within crossbred versus HO cows). Additionally, sire nested within breed group was a random variable. The MIXED procedure of SAS (release 9.4, SAS Institute Inc., Cary, NC) was used to conduct the ANOVA and to obtain solutions. Orthogonal contrasts between least squares means of production traits were performed for the effects of breed of cow and breed group. The $P$-values for the comparison of breed groups were subjected to the Bonferroni correction and used $\mathrm{HO}$ as the control to account for multiple comparisons with $\mathrm{HO}$ cows. Subsequently, the $P$-value for the comparison of $\mathrm{MO} \times \mathrm{HO}$ with $\mathrm{VR} \times$ $\mathrm{HO}$ cows was subjected to the Bonferroni correction with no control breed group designated.
Calving Traits. Herds were asked to follow the prescribed matings for the first 4 services and were permitted to use a nonprescribed AI bull or natural service bull on fifth and later services. Furthermore, some virgin heifers were mistakenly bred to a bull other than prescribed. Therefore, $6 \%$ of first lactation cows (90 crossbred and $47 \mathrm{HO}$ ) gave birth to calves that did not conform to the design of the study and the calving records of these cows were eliminated.

Cows were assigned to HYS for all calving traits in the same manner as production traits. For the analysis of TW, the HYS edit removed 9 crossbred and $82 \mathrm{HO}$ cows, and a total of 1,004 crossbreds $(496 \mathrm{MO} \times \mathrm{HO}$ and $508 \mathrm{VR} \times \mathrm{HO}$ cows) and $971 \mathrm{HO}$ cows remained. For the analysis of GL, CD, and SB, the twin births in each breed group $(3 \mathrm{MO} \times \mathrm{HO}, 4 \mathrm{VR} \times \mathrm{HO}$, and 6 HO cows) were removed. Subsequently, the HYS edit was applied to data for GL, CD, and SB and the HYS requirement removed 9 crossbred and $86 \mathrm{HO}$ cows. The number of cows analyzed for GL, CD, and SB was 997 crossbred $(493 \mathrm{MO} \times \mathrm{HO}$ and $504 \mathrm{VR} \times \mathrm{HO})$ and 961 HO cows.

The TW was evaluated with a chi-squared test (SAS) to determine probability of significant difference between breed groups. For the analysis of GL, CD, and $\mathrm{SB}$, the fixed effects included HYS of first calving, sex of calf, breed of calf (crossbred versus HO), breed group of calf $(\mathrm{MO} \times \mathrm{VR} / \mathrm{HO}$ or $\mathrm{VR} \times \mathrm{MO} / \mathrm{HO}$ nested within crossbred vs. HO), the interaction of breed of calf and sex of calf, and the interaction of breed group and sex of calf. Finally, sire of calf nested within breed group of calf was a random variable. The MIXED procedure of SAS was used to conduct the ANOVA and obtain solutions for GL and CD. Because SB was a binary trait, the MIXED procedure of SAS was used to obtain least squares means but the GLIMMIX procedure (SAS) was used to assess statistical significance of variables. Orthogonal contrasts were evaluated in the same manner as the production traits and employed the Bonferroni correction for comparisons between breed groups as well as the interaction of sex of calf with breed group.

\section{RESULTS AND DISCUSSION}

Results for combined crossbred breed groups are compared with the $\mathrm{HO}$ cows; however, results are also provided separately for $\mathrm{MO} \times \mathrm{HO}$ and $\mathrm{VR} \times \mathrm{HO}$ compared with $\mathrm{HO}$ cows (and for $\mathrm{MO} \times \mathrm{HO}$ versus $\mathrm{VR} \times$ $\mathrm{HO}$ crossbred cows when significant). The collective examination of both types of crossbreds provides a better reflection of the experience of herds initiating a 3-breed rotation using $\mathrm{MO}$ and VR bulls in a pure $\mathrm{HO}$ herd. 


\section{Production and SCS}

Most herds had aggressive goals to calve cows the first time at 22 or 23 mo of age, and the effect of HYS was highly significant $(P<0.01)$ for age at first calving. Herd E (Table 3 ) had especially low mean age at first calving $(22.2 \mathrm{mo})$. On the other hand, herd C preferred to calve cows at a substantially older age than the other 7 herds $(27.5 \mathrm{mo})$. The combined crossbred (23.8 mo) and pure HO cows (23.9 mo) were very similar for age at first calving (Table 4). Pure MO cows in France usually have older age at first calving than pure HO cows in the United States, but the reason for this difference is not likely because of genetics for growth, maturity, or fertility of the 2 breeds. Hazel et al. (2014) reported similar age at first calving for MO-sired crossbreds compared with $\mathrm{HO}$ cows in a single high-input confinement herd; however, MO-sired crossbreds calved 0.9 mo earlier than $\mathrm{HO}$ cows in a grazing herd in the same study. A Swedish study (Ericson et al., 1988) found heterosis for age at first calving of $+1.2 \%$, but reported only a 0.12 -mo difference, phenotypically, for $\mathrm{VR} \times \mathrm{HO}$ compared with $\mathrm{HO}$ cows. Results from this study indicate both $\mathrm{MO} \times \mathrm{HO}$ and $\mathrm{VR} \times \mathrm{HO}$ crossbred heifers can be managed together with pure HO heifers without concern for difference in age at first calving between breed groups.

The effect of HYS was highly significant $(P<0.01)$ for milk, fat, protein, and fat plus protein production as well as SCS during first lactation. Production of fluid volume of milk $(\mathrm{kg})$ was significantly lower $(P=0.04)$ for the combined crossbred cows $(-2 \%)$ than the HO cows (Table 4); however, the difference resulted from the $\mathrm{VR} \times \mathrm{HO}$ cows $(-4 \%)$ producing significantly less fluid volume of milk than the $\mathrm{HO}$ cows because the
$\mathrm{MO} \times \mathrm{HO}$ cows were not different from the $\mathrm{HO}$ cows Furthermore, the contrast of $\mathrm{MO} \times \mathrm{HO}$ with $\mathrm{VR} \times \mathrm{HO}$ cows indicated that the $\mathrm{VR} \times \mathrm{HO}$ cows produced less $(P=0.04)$ fluid volume of milk than the $\mathrm{MO} \times \mathrm{HO}$ cows. Fluid volume of milk has historically been an important barometer for measuring productivity of cows and continues to be used for day-to-day management of cow health. However, fat and protein production have become more commonplace as gauges for economic productivity of cows. Furthermore, a vast majority of herds in the United States are paid only for the solids $(\mathrm{kg})$ that milk contains. Predictions of future milk price are used in the United States to assign weights on traits in the Net Merit selection index (VanRaden and Cole, 2014), and those authors estimated a slightly negative weight ( $-\$ 0.006 /$ PTA unit) should be assigned to fluid volume of milk based on milk price forecasts for 2015 to 2019. Therefore, most dairy producers in the United States should compare productivity of breed groups of cows based on solids $(\mathrm{kg})$ production instead of on fluid volume of milk.

The combined crossbred cows in this study tended $(P$ $=0.09)$ to produce more $(+2 \%)$ fat $(\mathrm{kg})$ than the $\mathrm{HO}$ cows, and this resulted from the numerically greater fat production of both of the $\mathrm{MO} \times \mathrm{HO}(+9 \mathrm{~kg})$ and the $\mathrm{VR} \times \mathrm{HO}(+5 \mathrm{~kg})$, collectively, versus the $\mathrm{HO}$ cows (Table 4). Fat percentage was $+0.14 \%$ greater $(P<$ 0.01 ) for the combined crossbred cows than the HO cows. The VR breed is known for its high fat content of milk, and the VR $\times$ HO cows $(3.93 \%)$ had greater fat content $(P<0.01)$ compared with the $3.74 \%$ of the $\mathrm{HO}$ cows during first lactation.

The advantage $(+2 \%)$ of the combined crossbred cows versus $\mathrm{HO}$ cows for protein production $(\mathrm{kg})$ was similar to the results for fat production $(\mathrm{kg})$; however,

Table 4. Least squares means and standard errors for age at calving and 305-d production (actual basis, not mature equivalent) for both crossbred groups (pooled), Montbéliarde $\times$ Holstein crossbreds, and Viking Red $\times$ Holstein crossbreds compared with pure Holstein cows for first lactations

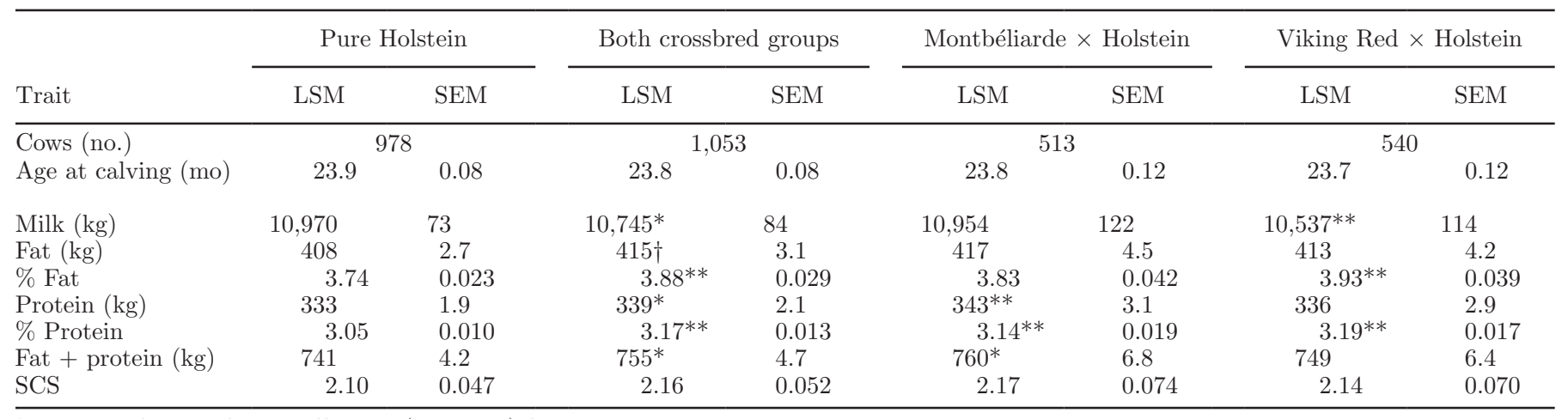

$\dagger$ Tendency for significant difference $(P<0.10)$ from pure Holsteins.

* Significant difference $(P<0.05)$ from pure Holsteins.

**Significant difference $(P<0.01)$ from pure Holsteins. 
the significance was greater $(P=0.02)$ because the standard errors for protein production were smaller than those for fat production (Table 4). Both crossbred groups had numerically higher protein production $(+10$ $\mathrm{kg}$ and $+3 \mathrm{~kg}$ for $\mathrm{MO} \times \mathrm{HO}$ and $\mathrm{VR} \times \mathrm{HO}$, respectively); however, only the comparison of $\mathrm{MO} \times \mathrm{HO}$ $(+3 \%)$ to $\mathrm{HO}$ cows was highly significant $(P<0.01)$. Both crossbred groups had significantly higher $(P<$ $0.01)$ protein percentage $(+0.10$ and $+0.16 \%$ for $\mathrm{MO}$ $\times \mathrm{HO}$ and $\mathrm{VR} \times \mathrm{HO}$, respectively) than the $\mathrm{HO}$ cows. These results agree with previous reports that pure MO and VR cows were superior to HO cows for protein percentages in milk (Dezetter et al., 2015; Jönsson, 2015).

For production of fat plus protein $(\mathrm{kg})$, the combined crossbreds were significantly $(P=0.03)$ higher than the HO cows $(+2 \%)$ during first lactation (Table 4$)$. The MO $\times$ HO cows had $+3 \%$ more fat plus protein production than $\mathrm{HO}$ cows; however, the $\mathrm{VR} \times \mathrm{HO}$ cows were statistically similar to their $\mathrm{HO}$ herdmates for fat plus protein production because of the higher percentages of fat and protein in their milk despite lower fluid volume of milk. Our analysis of the production traits did not adjust for pregnancy status (i.e., days open) of cows; however, a chi-squared test of the percentage of cows pregnant by 150 DIM indicated that significantly more $(P<0.02)$ of the $\mathrm{MO} \times \mathrm{HO}(76 \%)$ and $\mathrm{VR} \times \mathrm{HO}$ $(74 \%)$ cows were pregnant at 150 DIM compared with the HO cows (68\%). Consequently, the greater proportion of HO cows that were open at 150 DIM may have provided them with a reduced effect of pregnancy (i.e., greater late-lactation production) versus the crossbred cows during first lactation.

Results for 305-d production of fat and protein production $(\mathrm{kg})$ in this study differed somewhat from other recent comparisons of $\mathrm{MO} \times \mathrm{HO}$ and $\mathrm{VR} \times \mathrm{HO}$ with $\mathrm{HO}$ cows. Least squares means of fat, protein, and fat plus protein production were -2 to $-4 \%$ for $\mathrm{MO} \times$ $\mathrm{HO}$ compared with $\mathrm{HO}$ cows in studies by Heins et al. (2006b), Walsh et al. (2008), Heins and Hansen (2012), Hazel et al. (2014), and Dezetter et al. (2015). However, Heins and Hansen (2012) pointed out the MO sires that had the most daughters in their study had comparatively low ranking within breed for production. On the other hand, Malchiodi et al. (2014) found $\mathrm{MO} \times \mathrm{HO}$ had $+5 \%$ greater fat production $(\mathrm{kg})$ and equal protein production $(\mathrm{kg})$ to $\mathrm{HO}$ cows for first lactation. Other studies compared production of $\mathrm{VR} \times \mathrm{HO}$ with $\mathrm{HO}$ cows during first lactation (Heins et al., 2006b; Heins and Hansen, 2012; Malchiodi et al., 2014), and they reported the $\mathrm{VR} \times \mathrm{HO}$ cows ranged from -1 to $-7 \%$ for fat and protein production $(\mathrm{kg})$ compared with HO cows. Conversely, Swalve (2007) found VR $\times$ HO produced $+6 \%$ more fat $(\mathrm{kg})$ and $+8 \%$ more protein $(\mathrm{kg})$ than $\mathrm{HO}$ cows for a lower-production organic herd.
These earlier studies were often observational in nature or included a small number of cows. Therefore, perhaps, the more favorable results for production of the crossbreds in the current study can be explained by the use of high-ranking sires within all of the breed groups. Also, field data on crossbred cows could contain biases because herd owners may assign service sires based on phenotype of the dam (e.g., HO cows with poor fertility were bred to non-Holstein bulls, HO cows with large body size were bred to VR bulls, or HO cows with poor leg conformation were bred to MO bulls) or herd owners may intentionally breed their best cows to HO bulls, whereas lower-ranking $\mathrm{HO}$ cows are bred to bulls from a different breed. Differential mating of this nature was not possible in this study because of the meticulous assignment of foundation $\mathrm{HO}$ dams of cows by age or lactation number, sire, and production level within sire.

Results from this study provide evidence that crossbreeding may be well-suited for herds at high production levels in addition to those with low production levels. The first-lactation crossbred cows in this study met the production expectations of these high-performance herds. Kargo et al. (2012) grouped more than 1,700 Jersey herds in Denmark into 5 environmental categories according to level of protein production $(\mathrm{kg})$, and they found heterosis for production traits was independent of level of production for crosses of Danish and US strains of Jersey cows. The 8 herds in the current study varied little for mean fat $(\mathrm{kg})$ and protein $(\mathrm{kg})$ production during first lactation (Figure 1), and the range from lowest to highest herd mean was slightly greater than $100 \mathrm{~kg}$ of fat plus protein $(\mathrm{kg})$ production. Figure 1 reveals the combined crossbred cows had no loss of milk solids production $(\mathrm{kg})$ compared with $\mathrm{HO}$ cows during first lactation in any of the 8 herds. Each herd had similar selection criteria for AI bulls, but the bulls used were not identical across herds unlike the 2-herd study of Hazel et al. (2014). Consequently, the AI bulls used within each herd, combined with herdlevel management factors, influenced the degree of difference between the crossbred and HO breed groups for the 8 herds.

The SCS did not differ for combined crossbreds compared with $\mathrm{HO}$ cows during first lactation, and SCS was uniformly low for the breed groups (Table 4). Other studies that compared MO- and VR-sired crossbred with $\mathrm{HO}$ cows during first lactation had a range of results for SCS. Comparisons of $\mathrm{MO} \times \mathrm{HO}$ with HO cows by Walsh et al. (2008), Hazel et al. (2014), and Malchiodi et al. (2014) found no difference in SCS during first lactation; however, Dezetter et al. (2015) reported MO $\times$ HO cows (3.41) had lower SCS across lactations than HO cows (3.62), and Heins and Hansen (2012) found lower SCS in first lactation for $\mathrm{MO} \times \mathrm{HO}$ 
crossbreds (2.45) compared with HO cows (2.73). Studies of Norwegian Red $\times \mathrm{HO}$ crossbreds (Cartwright et al., 2012; Ezra et al., 2016), which share genetic similarity to VR $\times \mathrm{HO}$ crossbreds, reported no difference for SCS between the crossbred and HO cows. However, Heins and Hansen (2012) reported lower SCS for both VR-sired and Norwegian Red-sired crossbreds (2.53) compared with $\mathrm{HO}$ cows (2.73) in first lactation from a field study, and Malchiodi et al. (2014) also observed lower SCS for VR $\times \mathrm{HO}$ compared with $\mathrm{HO}$ cows $(2.35$ vs. 2.88, respectively) during first lactation. Contrarily, Swalve (2007) reported VR $\times$ HO cows had SCS of 3.18 , which was higher than the HO cows (2.75) for a German low-production organic herd. Problems with subclinical mastitis typically become more prevalent for cows in later lactations (Heins and Hansen, 2012), so the lack of difference between the crossbred and HO cows during first lactation in the current study was not surprising.

\section{Calving Traits}

No difference was detected between combined crossbred $(0.7 \%)$ and HO cows $(1.0 \%)$ for TW at first calving (Table 5). First-lactation cows tend to have low rates of TW compared with older cows, and a summary of TW studies by Wiltbank et al. (2000) reported only 0.7 to $1.3 \%$ TW at first calving. Fricke (2001) reported variation for TW may result from differences in breed composition of cows; however, production level of cows, hormonal treatments for infertility, or other management practices (all of which may vary for breed groups) could also affect TW. Multiple lactations of crossbred and $\mathrm{HO}$ cows must be compared to assess the extent these risk factors affect TW among crossbred versus HO cattle.

The effect of HYS significantly $(P<0.01)$ explained variation of GL and CD, but was not significant for SB. Sex of calf explained significant variation $(P<0.01)$ for GL, CD, and SB. Across breed groups, male calves had longer GL $(+2 \mathrm{~d})$, higher CD score $(+0.4)$, and greater SB $(+6 \%)$ than female calves. This result was anticipated because pure $\mathrm{HO}$ male calves had $+1.2 \mathrm{~d}$ longer GL compared with pure $\mathrm{HO}$ female calves for Norman et al. (2009), and MO-sired and pure HO male calves had greater GL $(+1.2$ and +2.0 d, respectively) than females studied by Heins et al. (2010). Results of this study are in accordance with the literature for CD and SB with male calves having more CD and greater SB than female calves (Lombard et al., 2007).

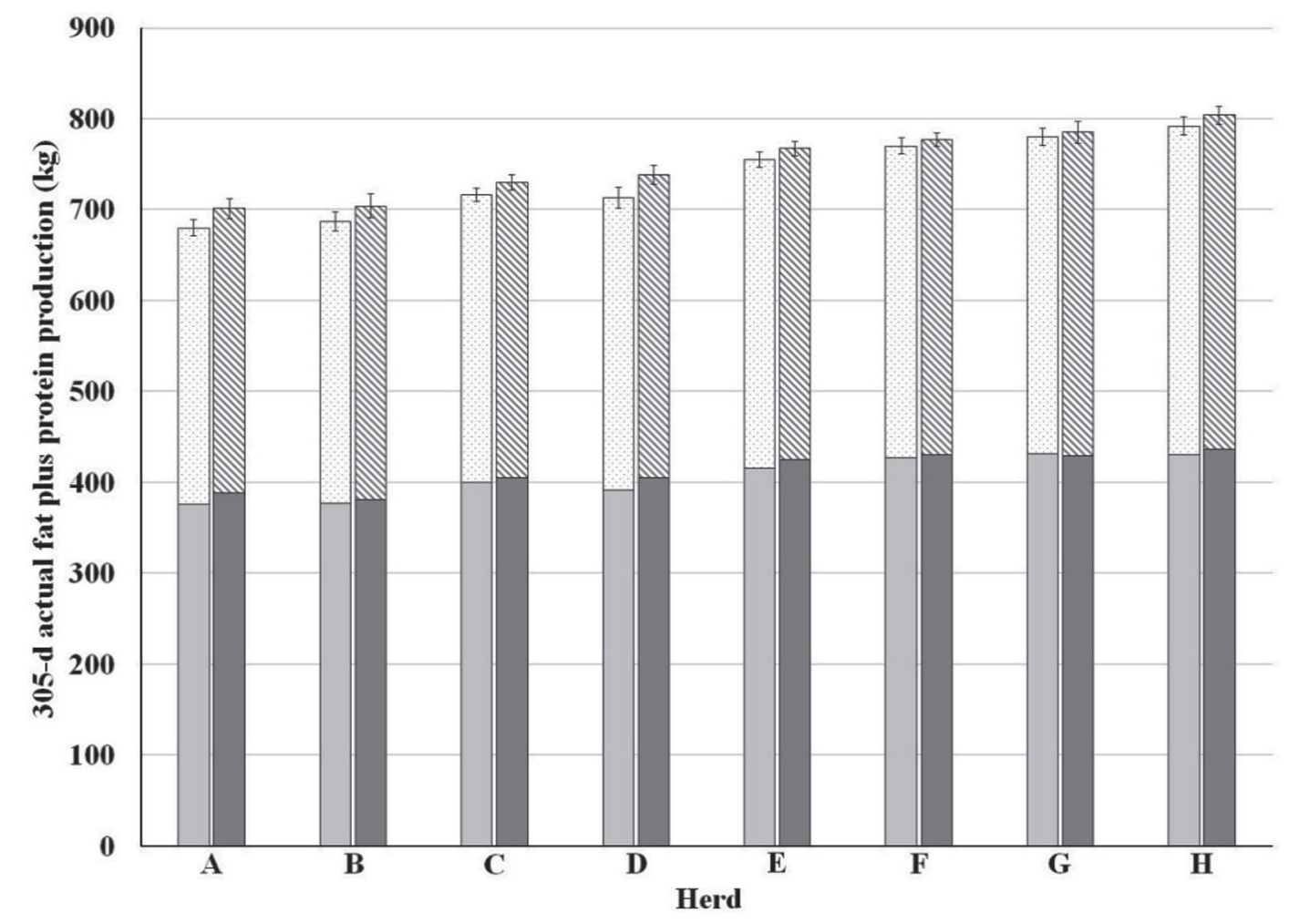

Figure 1. Least squares means of 305-d fat production $(\mathrm{kg})$ of pure Holstein (light gray bars) and both crossbred groups (dark gray bars), protein production $(\mathrm{kg})$ of pure Holstein (dotted bars) and both crossbred groups (diagonal striped bars), and SEM of fat plus protein production $(\mathrm{kg})$ for 8 Minnesota herds during first lactation. 
Table 5. Least squares means and standard errors for twinning rate, gestation length, calving difficulty score (1-5 scale), and stillbirth rate for both crossbred groups (pooled), Montbéliarde $(\mathrm{MO}) \times$ Holstein $(\mathrm{HO})$ crossbreds, and Viking Red $($ VR) $\times$ Holstein crossbreds compared with pure Holstein cows for first calving

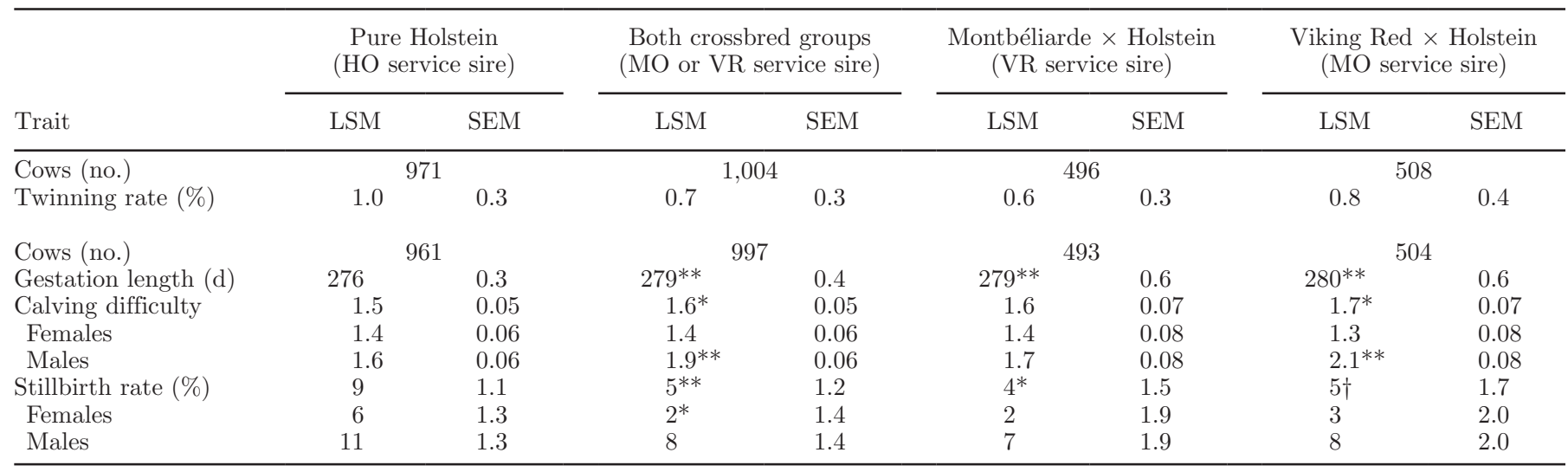

$\dagger$ Tendency for significant difference $(P<0.10)$ from pure Holsteins.

* Significant difference $(P<0.05)$ from pure Holsteins.

** Significant difference $(P<0.01)$ from pure Holsteins.

Both the $\mathrm{MO} \times \mathrm{HO}$ cows (bred to VR bulls) and the $\mathrm{VR} \times \mathrm{HO}$ cows (bred to MO bulls) had significantly $(P$ $<0.01)$ longer GL $(+3$ and $+4 \mathrm{~d}$, respectively) than the $\mathrm{HO}$ cows bred to HO bulls (Table 5). The interaction of sex of calf with breed group was not significant, which indicated the 3-breed crossbred calves had longer GL than HO calves regardless of sex of calf. The GL of cows is primarily influenced by the genetics of the calf, and the 3-breed crossbred calves averaged either 25 or $50 \%$ MO content. The MO breed, like its related breeds of Brown Swiss and Fleckvieh, has significantly longer GL than the other major breeds of dairy cattle. Norman et al. (2009) reported Brown Swiss cows had +9 d longer GL than HO cows calving for the first time, and the MO breed has $+7 \mathrm{~d}$ longer GL than the HO breed in France (Ledos and Moureaux, 2013). The GL of the $\mathrm{HO}$ cows was $276 \mathrm{~d}$, which is $2 \mathrm{~d}$ shorter than the GL reported by Norman et al. (2009) for HO first-calf heifers (278 d). However, Norman et al. (2009) also observed a 0.8-d shorter GL for heifers conceiving at young $(<14 \mathrm{mo})$ versus old $(>20 \mathrm{mo})$ ages, and cows in the current study conceived and calved at very young ages.

The combined crossbred cows in this study had significantly $(P=0.05)$ more $\mathrm{CD}$ than $\mathrm{HO}$ cows $(1.6$ vs. 1.5 , respectively) when evaluated subjectively on a 1 (no assistance) to 5 (extreme difficulty) scale. However, statistical tests of the interaction of sex of calf with breed group revealed the numerically small, but significant, difference between breeds (one-tenth of 1 score) for $C D$ was due entirely to the significantly greater $\mathrm{CD}$ for male MO-sired calves that were born to $\mathrm{VR} \times$ HO first-calf dams (Table 5). The heifer calves of the same breed group actually had the numerically lowest CD (1.3) among all the combinations of sex and breed groups. Contrasts between the 2 crossbred breed groups for CD were not significant for both sexes combined, nor for female calves independently; however, the male MO-sired calves $(2.1)$ had greater CD $(P=0.03)$ than the male VR-sired crossbred calves (1.7). Results for CD in this study were contrary to those found in the field study of Heins et al. (2006a), who reported significantly fewer difficult births for MO $\times$ HO cows $(7.2 \%)$ and $\mathrm{VR} \times \mathrm{HO}(3.7 \%)$ compared with $\mathrm{HO}$ cows $(17.7 \%)$; however, the cows in that study were bred to various breeds of AI bulls with no mating design. Birth weights of calves were not available for the current study; however, a possible explanation for the greater $\mathrm{CD}$ of male MO-sired calves could be a significant $(P<0.01)$ positive correlation between GL and CD, which may have potentially resulted from greater birth weights. The Pearson correlations between GL and CD were 0.09 for HO calvings and 0.20 for combined crossbred calvings, which are lower than the 0.27 correlation of sire EBV for GL and CD from Danish national data of HO calvings (Hansen et al., 2004).

Differences for SB between the breed groups were highly significant $(P<0.01)$ and favored the $\mathrm{MO} \times$ $\mathrm{HO}$ and VR $\times \mathrm{HO}$ crossbreds (4 and $5 \%$, respectively) compared with pure HO (9\%) at first calving (Table 5). Contrary to results for CD, the 2 interactions involving sex of calf with the breed groups were not significant, which indicated the crossbred calves had less SB than $\mathrm{HO}$ calves regardless of sex of calf. Typically, CD has a positive relationship with $\mathrm{SB}$ within the $\mathrm{HO}$ breed (Lombard et al., 2007); however, the $\mathrm{MO} \times \mathrm{VR} / \mathrm{HO}$ 
bull calves (8\%) did not have more SB than the pure HO bull calves (11\%) despite the greater CD of the MO $\times \mathrm{VR} / \mathrm{HO}$ bull calves.

Direct heterosis (due to the genetics of the calf) of $\mathrm{CD}$ and SB was negative (unfavorable) in the literature reviewed by Sørensen et al. (2008), and they estimated -10 to $-15 \%$ direct heterosis for CD and -5 to $-10 \%$ direct heterosis for SB. On the other hand, maternal heterosis (due to the genetics of the cow) for CD and SB was opposite in sign (positive) and of similar magnitude (Sørensen et al., 2008). Besides this, breeds are expected to differ for additive genetic effects for CD and SB. For the breeds included in this study, pure VR cows had 18\% lower CD and 36\% less SB at first calving than HO cows evaluated in Sweden (Jönsson, 2015); therefore, the numerical superiority for CD and SB of VR-sired 3-breed calves compared with the MO-sired 3-breed calves in this study was anticipated. Both CD and SB are economically important traits because cows experiencing CD require extra labor, and moderate to severe CD necessitates high costs of health treatments for cows giving birth.

Herd owners are accustomed to SB in excess of $8 \%$ for pure $\mathrm{HO}$ calves born to first lactation dams (Lombard et al., 2007; Sørensen et al., 2008), and some published studies estimate SB to be greater than $12 \%$ for first calving (Ettema and Santos, 2004; Heins et al., 2006a). VanRaden and Cole (2014) estimated the lost revenue for each SB calf at $\$ 300$ for the calculation weights for the Net Merit index; therefore, the extent of economic loss from SB calves was substantially lower for crossbred versus $\mathrm{HO}$ calves in this study.

The revenue from milk production (volume, component, and SCC pay adjustments), as well as the value of live calves born, will eventually contribute to a comprehensive analysis of the profitability of the $\mathrm{MO} \times$ $\mathrm{HO}$ and VR $\times \mathrm{HO}$ versus $\mathrm{HO}$ cows in this study on a lifetime basis. Previous studies on crossbreeding in dairy cattle have usually been limited to comparisons of performance for routinely measured traits (e.g., production traits, SCS, fertility, and survival), and most of the studies reported traits divided into single parities. An exception is the study of Heins et al. (2012), which reported lifetime profitability and profit per day in the herd for crossbred cows $(+5.3$ and $+3.6 \%$ for $\mathrm{MO} \times \mathrm{HO}$ and $\mathrm{VR} \times \mathrm{HO}$, respectively) compared with HO cows. More studies of this nature are needed because the comparisons of individual traits ignores any potential antagonism between traits, relies heavily on intuition to assign economic value to the traits, and considers only the value of outputs without regard to inputs. Furthermore, the welfare of dairy cattle is of increasing concern to consumers, and measures of profitability may be more reflective of animal well-being than some measures of performance, especially milk production (Oltenacu and Broom, 2010). The effect of health costs of cows on lifetime profitability has not been considered in most research of crossbreeding, and the 8 herd owners in this study (and likely most other dairy producers) place high value on the economic effects of cow health.

\section{CONCLUSIONS}

Potential loss of production is often mentioned as a reason to avoid crossbreeding in dairy cattle. Concerns about lost production may be legitimate when heterosis in not fully exploited (either by rotating only 2 breeds or by using breeds which are genetically similar), inappropriate breeds are used out of familiarity or convenience, or when AI bulls of low genetic rank are selected. This study was designed and implemented to mitigate those concerns by focusing on 8 high-performance Minnesota herds that used a 3-breed rotational crossbreeding system with the use of high-ranking AI bulls from the MO, VR, and HO breeds. Furthermore, most estimates of the negative effects of inbreeding are dated and, perhaps, recent selection practices in the pure HO breed has exacerbated the potential effect of inbreeding depression. The 2-breed crossbreds in this study met the production expectations of the 8 participating dairy herds. In fact, the $\mathrm{MO} \times \mathrm{HO}$ and VR $\times$ HO crossbreds, collectively, had greater production of milk solids $(\mathrm{kg})$ in first lactation with similar SCS compared with their pure HO herdmates. The CD of the VR-sired 3-breed crossbred calves was similar to pure $\mathrm{HO}$; however, the male MO-sired calves out of $\mathrm{VR} \times \mathrm{HO}$ dams had somewhat greater $\mathrm{CD}$ than male HO calves. The SB rate of crossbred calves was onehalf that of the pure $\mathrm{HO}$ calves, and this is a major advantage for both profitability and animal welfare. In the future, the lifetime performance and profitability of the crossbred versus pure $\mathrm{HO}$ cows in this study will be compared, including the costs of health treatments, fertility, and survival.

\section{ACKNOWLEDGMENTS}

The authors express gratitude to the owners/managers of the 8 dairies for their participation in this study and for providing data on the cows in their herds. The authors also thank Minnesota Select Sires Co-op Inc. for its contributions of mating individual heifers and cows with AI bulls. Funding for this project was provided by Coopex Montbéliarde (Roulans, France), Viking Genetics (Randers, Denmark), Creative Genetics of California (Oakdale, CA), Select Sires Inc. (Plain 
City, $\mathrm{OH}$ ), and Minnesota Select Sires Co-op Inc. (St. Cloud, MN).

\section{REFERENCES}

Blöttner, S., B. J. Heins, M. Wensch-Dorendorf, L. B. Hansen, and H. H. Swalve. 2011. Brown Swiss $\times$ Holstein crossbreds compared with pure Holsteins for calving traits, body weight, backfat thickness, fertility, and body measurements. J. Dairy Sci. 94:1058-1068.

Cartwright, S. L., L. R. Schaeffer, E. B. Burnside, and B. A. Mallard. 2012. Adaptive immune response, survival, and somatic cell score between postpartum Holstein and Norwegian Red $\times$ Holstein firstcalf heifers. J. Anim. Sci. 90:2970-2978.

Cole, J. B., and P. M. VanRaden. 2009. A manual for use of BESTPRED: A program for estimation of lactation yield and persistency using best prediction. Release 2.0 rc 6 . Animal Improvement Programs Lab, USDA, Beltsville, MD.

Council on Dairy Cattle Breeding. 2016. Trend in inbreeding coefficients of cows for Holstein or Red \& White. Accessed Feb. 8, 2017. https://www.uscdcb.com/eval/summary/inbrd.cfm.

Dechow, C. D. 2014. Options exist to confront inbreeding. Page 218 in Hoards Dairyman. Mar. 25, 2014. W. D. Hoard and Sons, Fort Atkinson, WI.

Dechow, C. D., G. W. Rogers, J. B. Cooper, M. I. Phelps, and A. L. Mosholder. 2007. Milk, fat, protein, somatic cell score, and days open among Holstein, Brown Swiss, and their crosses. J. Dairy Sci. 90:3542-3549.

Department of Agriculture, Food and the Marine. 2015. AIM bovine statistics report 2015. Accessed Jun. 2, 2016. http://www.agriculture. gov.ie/animalhealthwelfare/animalidentificationmovement/ cattle/.

Dezetter, C., H. Leclerc, S. Mattalia, A. Barabat, D. Boichard, and V. Ducrocq. 2015. Inbreeding and crossbreeding parameters for production and fertility traits in Holstein, Montbéliarde, and Normande cows. J. Dairy Sci. 98:4904-4913.

Ericson, K., B. Danell, and J. Rendel. 1988. Crossbreeding effects between two Swedish dairy breeds for production traits. Livest. Prod. Sci. 20:175-192.

Ettema, J. F., and J. E. P. Santos. 2004. Impact of age at calving on lactation, reproduction, health, and income in first-parity Holsteins on commercial farms. J. Dairy Sci. 87:2730-2742.

Ezra, E., M. Van Straten, and J. I. Weller. 2016. Comparison of pure Holstein to crossbred Holsteins with Norwegian Red cattle in first and second generations. Animal 10:1254-1262.

Fricke, P. M. 2001. Twinning in dairy cattle. Accessed Feb. 8, 2017. https://host.cals.wisc.edu/dairyscience/wp-content/uploads/ sites/40/2013/11/Fricke-Twinning.pdf.

Hansen, M., M. S. Lund, J. Pedersen, and L. G. Christensen. 2004. Gestation length in Danish Holsteins has weak genetic associations with stillbirth, calving difficulty, and calf size. Livest. Prod. Sci. 91:23-33.

Hazel, A. R., B. J. Heins, A. J. Seykora, and L. B. Hansen. 2014. Production, fertility, survival, and body measurements of Montbéliarde-sired crossbreds compared with pure Holsteins during their first 5 lactations. J. Dairy Sci. 97:2512-2525.

Heins, B. J., and L. B. Hansen. 2012. Short communication: Fertility, somatic cell score, and production of Normande $\times$ Holstein, Montbéliarde $\times$ Holstein, and Scandinavian Red $\times$ Holstein crossbreds versus pure Holsteins during their first 5 lactations. J. Dairy Sci. 95:918-924.

Heins, B. J., L. B. Hansen, and A. De Vries. 2012. Survival, lifetime production, and profitability of crossbreds of Holstein with Normande, Montbéliarde, and Scandinavian Red compared to pure Holstein cows. J. Dairy Sci. 95:1011-1021.

Heins, B. J., L. B. Hansen, A. R. Hazel, A. J. Seykora, D. G. Johnson, and J. G. Linn. 2010. Birth traits of pure Holstein calves versus Montbéliarde-sired crossbred calves. J. Dairy Sci. 93:2293-2299.
Heins, B. J., L. B. Hansen, and A. J. Seykora. 2006a. Calving difficulty and stillbirths of pure Holsteins versus crossbreds of Holstein with Normande, Montbéliarde, and Scandinavian Red. J. Dairy Sci. 89:2805-2810.

Heins, B. J., L. B. Hansen, and A. J. Seykora. 2006b. Production of pure Holsteins versus crossbreds of Holstein with Normande, Montbéliarde, and Scandinavian Red. J. Dairy Sci. 89:2799-2804.

Jönsson, R. 2015. Estimation of heterosis and performance of crossbred Swedish dairy cows. MS Thesis. Department of Animal Breeding and Genetics, Swedish University of Agricultural Sciences, Uppsala.

Kargo, M., P. Madsen, and E. Norberg. 2012. Short communication: Is crossbreeding only beneficial in herds with low management level? J. Dairy Sci. 95:925-928.

Ledos, H., and S. Moureaux. 2013. Durée de gestation pour les principales races de l'espéce bovine: Moyenne et variabilité. Accessed Jul. 12, 2016. http://idele.fr/?eID=cmis_download\&oID=workspace:// SpacesStore/6e1935c2-3970-4fb3-9320-30f29165866e.

LIC and Dairy NZ. 2015. New Zealand dairy statistics 2014-15. Accessed Jun. 29, 2016. http://www.dairynz.co.nz/media/3136117/ new-zealand-dairy-statistics-2014-15.pdf.

Lombard, J. E., F. B. Garry, S. M. Tomlinson, and L. P. Garber. 2007. Impacts of dystocia on health and survival of dairy calves. J. Dairy Sci. 90:1751-1760.

Malchiodi, F., A. Cecchinato, M. Penasa, C. Cipolat-Gotet, and G. Bittante. 2014. Milk quality, coagulation properties, and curd firmness modeling of purebred Holsteins and first- and secondgeneration crossbred cows from Swedish Red, Montbéliarde, and Brown Swiss bulls. J. Dairy Sci. 97:4530-4541.

Nordic Cattle Genetic Evaluation. 2016. NTM-Nordic Total Merit. Accessed Jun. 6, 2016. http://www.nordicebv.info/en/ntm-nordictotal-merit-2/.

Norman, H. D., L. M. Walton, and J. Dürr. 2015. Reasons that cows in dairy herd improvement programs exit the milking herd (2014). Accessed Feb. 9, 2017. https://www.uscdcb.com/publish/dhi/ dhi15/cullall.html.

Norman, H. D., J. R. Wright, M. T. Kuhn, S. M. Hubbard, J. B. Cole, and P. M. VanRaden. 2009. Genetic and environmental factors that affect gestation length in dairy cattle. J. Dairy Sci. 92:22592269.

Oltenacu, P. A., and D. M. Broom. 2010. The impact of genetic selection for increased milk yield on the welfare of dairy cows. Anim. Welf. 19(Suppl. 1):39-49.

O. S. Montbéliarde. 2016. The Unique Synthesis Index (ISU), the steering tool of the Montbéliarde selection. Accessed May 4, 2016. http://www.montbeliarde.org/en-428.html.

Sørensen, M. K., E. Norberg, J. Pedersen, and L. G. Christensen. 2008. Invited review: Crossbreeding in dairy cattle: A Danish perspective. J. Dairy Sci. 91:4116-4128.

Swalve, H. H. 2007. Crossbreeding in dairy cattle: International trends and results from crossbreeding data in Germany. Lohmann Inf. 42:38-46.

VanRaden, P. M., and J. B. Cole. 2014. AIP Research Report NM\$5: Net merit as a measure of lifetime profit: 2014 revision. Accessed Jun. 6, 2016. http://aipl.arsusda.gov/reference/nmcalc-2014.htm.

VanRaden, P. M., and A. H. Sanders. 2003. Economic merit of crossbred and purebred US dairy cattle. J. Dairy Sci. 86:1036-1044.

Walsh, S., F. Buckley, K. Pierce, N. Bryne, J. Patton, and P. Dillon. 2008. Effects of breed and feeding system on milk production, body weight, body condition score, reproductive performance, and postpartum ovarian function. J. Dairy Sci. 91:4401-4413.

Weigel, K. A., and K. A. Barlass. 2003. Results of a producer survey regarding crossbreeding on US dairy farms. J. Dairy Sci. 86:41484154 .

Wiltbank, M. C., P. M. Fricke, S. Sangsritavong, R. Sartori, and O. J. Ginther. 2000. Mechanisms that prevent and produce double ovulations in dairy cattle. J. Dairy Sci. 83:2998-3007. 